\begin{tabular}{l}
\multicolumn{5}{l}{ INTER NATIONAL BULLETIN OF BACTERIOLOGICAL } \\
NOMENCLATURE AND TAXONOMY \\
Volume 5
\end{tabular}

\title{
CHANGE IN THE METHODS OF DESIGNATION OF NEW SALMONELLA SEROTYPES
}

\author{
W. H. Ewing
}

Secretary of Enterobacteriaceae Subcommittee

At the September 8, 1953 meeting of the Enterobacteri aceae Subcommittee held in Rome, Italy, during the VI Congress for Microbiology, a majority of those present voted in favor of the following Addendum to the Subcommittee Report:

"It is the recommendation of the Enterobacteriaceae Subcommittee that from the date of publication of this report all new serological types of Salmonella should be described by formula only and not by name."

This Addendum was duly recorded in the Minutes of the September 8, 1953 Subcommittee meeting and was published in the Enterobacteriaceae Subcommittee Reports (Internatl. Bull. Bact. Nomen. and Tax. 4:73. 1954). Some months after publication of the Subcommittee Reports, several Subcommittee members requested the Subcommittee Chairman to ask the membership to consider cancellation of the abovementioned Addendum. Therefore, at the Chairman's request, the Secretary sent (December 21, 1954) a ballot to each Subcommittee member and asked for a vote either in favor of or against cancellation of the decision made on September 8, 1953 to describe new Salmonella serotypes by formula only. It was pointed out at that time that the vote was for or against an emendation of the Minutes of the September 8, 1953 Subcommittee meeting and a consequent change in the Report. On February 1, 1955, the Secretary informed the Chairman and the Subcommittee membership of the result of the voting, which was as follows:

13 voted in favor of cancellation (The Subcommittee Chairman also favors cancellation, but since there was a majority opinion, the Chairman's vote was not required).

2 voted not in favor of cancellation. 1 abstained.

The results of the voting indicated clearly that the major ity of the Subcommittee membership favored cancellation of the above-mentioned Addendum to the Minutes of the September 8, 1953 Subcommittee meeting in Rome, deletion of the Addendum from the Subcommittee Report (lines 5-8, page 
73), and a return to the earlier method of describing new Salmonella serotypes by a name and their antigenic formula.

The attached list of names and references for Salmonella serotypes that were described by formula only was supplied by Dr. F. Kauffmann.

\section{ADDENDUM}

Names of Salmonella Serotypes Published Without Names

Nomina nova proposed by Dr. F. Kauffmann

Salmonella brazzaville $=6,7: b: 1,2$

Typed by LeMinor, Merveille, Bascoulergue and Audebaud

(Annal. Inst. Pasteur 87:105. 1954).

Salmonella kapemba $=9,12: 1, \mathrm{v}: 1,7$

Typed by Kauffmann, Delville, Bouckaert, and Ballion

(Acta Path. et Microbiol. Scand. 35:307. 1954).

Salmonella minneapolis $=(3),(15), 34: \mathrm{e}, \mathrm{h}: 1,6$

Typed by Edwards, Kauffmann, and McWhorter

(Acta Path. et Microbiol. Scand. 35:67. 1954).

Salmonella boecker $=6,14: 1, \mathrm{v}: 1,7$

Typed by Boecker and Kauffmann

(Acta Path. et Microbiol. Scand. 34:101. 1954).

Salmonella landau $=30: i: 1,2$

Typed by Güther and Hanser

(Zbl. Bakt. I Orig. 161:363. 1954).

Salmonella kingabwa $=43: y: 1,5$

Typed by Kauffmann and Vendepitte

(Acta Path. et Microbiol. Scand. 35:71. 1954).

Salmonella hull $=16: b: 1,2$

Typed by Alexander, Douglas, and Taylor

(Monthly Bull. Min. Health, London. 13:117. 1954).

Salmonella manila $=3,15: \mathrm{z}_{10}: 1,5$

Typed by Edwards, Kauffmann, and McWhorter

(Acta Path. et Microbiol. Scand. 35:67, 1954). 